\title{
Gastrointestinal $\beta_{2}$ microglobulin amyloidosis in hemodialysis patients: biochemical analysis of amyloid proteins in small formalin-fixed paraffin-embedded tissue specimens
}

\author{
Batia Kaplan ${ }^{1,2}$, Brian M Martin ${ }^{3}$, Alejandro Livoff ${ }^{4}$, Dimitri Yeremenko ${ }^{4}$, Avi Livneh ${ }^{1,2}$ \\ and Hector I Cohen ${ }^{4}$ \\ ${ }^{1}$ Heller Institute of Medical Research, Sheba Medical Center, Tel-Hashomer, Israel; ${ }^{2}$ Tel-Aviv University, \\ Sackler School of Medicine, Tel-Aviv, Israel; ${ }^{3}$ Laboratory of Neurotoxicology, National Institute of Mental \\ Health, Bethesda, MD, USA and ${ }^{4}$ Department of Pathology, Western Galilee Hospital, Nahariya Medical \\ Center, Nahariya, Israel
}

\begin{abstract}
We present here a first report on the biochemical analysis of intestinal amyloid deposits found in two cases of hemodialysis-related amyloidosis. A new microtechnique was applied for extraction and immunochemical/ chemical characterization of amyloid proteins in small amounts of fixed tissue, thus allowing precise identification of $\beta_{2}$ microglobulin amyloid $\left(A \beta_{2} M\right)$ in both cases studied. The molecular mass of the identified amyloid $\beta_{2} \mathrm{M}$ was close to that of intact $\beta_{2} \mathrm{M}(12 \mathrm{kDa})$, with no evidence of the products of proteolytic fragmentation of these molecules. The isoelectrofocusing of the purified $A \beta_{2} M$ demonstrated a shift to more acidic $\mathrm{pl}$ as compared to the normal $\beta_{2} \mathrm{M}$ analyzed under the same experimental conditions. The obtained data suggest that the intestinal amyloid deposits in dialysis-related amyloidosis contain disease-specific $\beta_{2} \mathrm{M}$ isoforms, which could play a role in the pathogenesis of amyloid disease. The new methodology used might be useful in obtaining precise diagnosis of amyloidosis that is necessary for appropriate therapy, and also provide new important information on the chemical structure of amyloid proteins.

Modern Pathology (2005) 18, 1610-1617. doi:10.1038/modpathol.3800477; published online 2 September 2005
\end{abstract}

Keywords: amyloid; $\beta_{2}$ microglobulin; dialysis-related amyloidosis; electrophoresis; intestine; isoelectrofocusing

Dialysis-associated $\beta_{2}$ microglobulin $\left(\beta_{2} \mathrm{M}\right)$ amyloidosis is a disabling complication affecting patients maintained on long-term hemodialysis. ${ }^{1-3}$ Early studies showed that accumulation and deposition of $\beta_{2}$ microglobulin amyloid proteins $\left(\mathrm{A} \beta_{2} \mathrm{M}\right)$ occurs predominantly in the bones, tendons and joints. ${ }^{4-8}$ The major clinical manifestations of this disease include carpal tunnel syndrome, chronic synovytis, progressive bone destruction and pathological bone fractures. Marked increase in $\beta_{2} \mathrm{M}$ plasma concentration is probably necessary, but it is not sufficient to induce $\beta_{2} \mathrm{M}$ amyloidosis. Attempts were made to determine the precise chemical structure of $\mathrm{A} \beta_{2} \mathrm{M}$ proteins in order to reveal subtle structural changes responsible for the amyloid fibril formation and deposition. Although some authors stated that

Correspondence: Dr B Kaplan, PhD, Heller Institute of Medical Research, Sheba Medical Center, Tel-Hashomer 52621, Israel. E-mail: kaplanb@sheba.health.gov.il

Received 31 May 2005; accepted 10 July 2005; published online 2 September 2005 proteolysis of $\beta_{2} \mathrm{M}$ is necessary for fibrilogenesis, ${ }^{9}$ other studies showed that amyloid deposits are composed of intact $12 \mathrm{kDa}$ molecules. ${ }^{4,8}$ A possibility was raised that in contrast to the normal circulating $\beta_{2} \mathrm{M}$, the deposited $\mathrm{A} \beta_{2} \mathrm{M}$ proteins contain some acidic isoforms. ${ }^{10-12}$ The appearance of these isoforms was explained by deamination of Asn $17^{13,14}$ or modification by advanced glycation end products (AGE), ${ }^{10,12}$ but these findings have not been confirmed by other authors. ${ }^{15}$ In addition, presence of acidic $\beta_{2} \mathrm{M}$ isoforms has been demonstrated in normal urine, thus bringing up the question whether these isoforms are specific to dialysis-related amyloidosis. ${ }^{15}$ The importance of the $\beta_{2} \mathrm{M}$ structure-unrelated factors in the pathogenesis of dialysis-related amyloidosis has been proposed by implying the role of other proteins and cells under chronic inflammatory stress conditions and by raising questions of bioincompatibility of membranes or insufficient purity of water used for dialysis. ${ }^{16,17}$ Thus, the existence of the diseasespecific modifications of $\beta_{2} \mathrm{M}$ structure and their 
role in the pathogenesis of amyloid disease remain questionable.

Although dialysis-associated amyloidosis was initially believed to be limited to osteoarticular tissue, the involvement of visceral organs (gastrointestinal tract, liver, heart, prostate, kidneys, endocrine glands and subcutaneous tissue) is now well recognized..$^{2-4}$ However, in contrast to the extensive studies of $\mathrm{A} \beta_{2} \mathrm{M}$ in the osteoarticular tissues, amyloid deposition in the extra-articular tissues was examined only by routine histological and immunohistochemical techniques, and not biochemically. As a result, little is known about the precise chemical structure of $\mathrm{A} \beta_{2} \mathrm{M}$ deposited in the extra-articular tissues of patients with dialysis-related amyloidosis.

We present here a first report on the biochemical analysis of intestinal amyloid deposits found in two cases of hemodialysis-related amyloidosis. To overcome the difficulties of biochemical analysis of amyloid proteins related to small amounts of available tissue material and its fixation with formalin, we employed our new microtechnique allowing the extraction and immunochemical/chemical characterization of amyloid proteins in tiny amounts of fixed tissue. ${ }^{18}$ In both cases studied, the molecular mass of the identified amyloid $\beta_{2} \mathrm{M}$ was close to that of normal intact $\beta_{2} \mathrm{M}$, with no evidence of the products of proteolytic fragmentation of these molecules. The isoelectrofocusing (IEF) of the purified $\mathrm{A} \beta_{2} \mathrm{M}$ demonstrated a shift to more acidic pI values as compared to the normal $\beta_{2} \mathrm{M}$. The obtained data suggest that the intestinal amyloid deposits in dialysis-related amyloidosis contain disease-specific $\beta_{2} \mathrm{M}$ isoforms, which may play a role in the pathogenesis of amyloid disease.

\section{Patients and methods}

\section{Patients}

In case I, the 64-year-old female was started on hemodialysis in 1980. The cause of kidney failure was unknown. In 1998, the patient was admitted to the hospital because of the obstructive ileus due to volvulus. Subtotal colectomy was performed and a specimen was examined histopathologically and biochemically as described below. After 4 years, she succumbed due to septicemia complicating femoral fracture. In case II, the 78-year-old female with endstage renal failure of an unknown etiology was maintained on hemodialysis for 13 years. She was admitted to the hospital for acute abdomen secondary to colonic perforation. Hemicolectomy was performed, and a segment of the resected colon was subjected to histopatological and biochemical examination as described below.

\section{Pathological Methods}

Tissues were fixed in $4 \%$ buffered formalin. Formalin-fixed paraffin-embedded colon tissue speci- mens were subjected to histological and immunohistochemical examination. Sections were stained with hematoxylin and eosin (H\&E), Crystal Violet and Congo-red according to the standard methods. Microwave antigen retrieval technique was employed for the immunostaining of tissue sections with rabbit anti-human antibodies to $\beta_{2} \mathrm{M}, 1: 100$ (Zymed, San-Francisco, CA, USA). Bound antibodies were detected by the avidin-biotin-peroxidase method according to the established protocols.

\section{Extraction and Purification of Amyloid Proteins}

Amyloid proteins were recovered from the formalinfixed paraffin-embedded biopsy tissue by the formic acid extraction procedure described previously. ${ }^{18,19}$ Briefly, tissue specimen was deparaffinized at $60^{\circ} \mathrm{C}$, washed in xylene and rehydrated in decreasing concentrations of alcohol. The obtained tissue material was homogenized, washed with phosphate-buffered saline and centrifuged. The resulting pellet was suspended in concentrated formic acid overnight, centrifuged, and the obtained supernatant was dried in a Speed Vac apparatus.

\section{Sodium Dodecyl Sulfate Polyacrylamide Gel Electrophoresis (SDS-PAGE)}

SDS-PAGE was performed using the precast $20-25 \%$ polyacrylamide LongLife microgels (Gradipore, Frenchs Forest, Australia) as described. ${ }^{18,19}$ The material extracted from 2-5 mg fixed tissue sample was applied per well and run with Tris HEPES buffer (Gradipore). For the visualization of the proteins, the electrophoresed proteins were blotted onto Sequi-Blot PVDF (polyvinylidene difluoride) membranes (Bio Rad, Hercules, CA, USA) using Gradipore LongLife Transfer buffer, and afterwards stained with Coomassie blue R-250.

\section{Western Blot Analysis}

The electrophoresed proteins were transferred onto nitrocellulose (Schleicher and Schuell, Dassel, Germany) with a Gradipore LongLife Transfer buffer. The blots were immunostained with polyclonal rabbit antibodies to human immunoglobulin kappa $(\kappa)$ and lambda $(\lambda)$ light chains, and to $\beta_{2} \mathrm{M}$ (Dako, Carpinteria, CA, USA) as described earlier. ${ }^{18-20}$ Proteins were visualized using Super-Signal West Pico Chemiluminescent Substrate (Pierce, Rockford, IL, USA).

\section{Amino-Acid Sequence Analysis}

For N-terminal amino-acid sequence analysis, proteins run by SDS-PAGE were blotted onto Sequi-Blot PVDF (polyvinylidene difluoride) membranes (Bio Rad). The blotted protein bands (visualized with 
Coomassie blue R-250) were excised and subjected to amino-acid sequence analysis as described. ${ }^{18,19}$

\section{Micropreparative Purification of the Extracted Amyloid Proteins}

The SDS-PAGE procedure described above was employed for concentration and micropreparative purification of amyloid proteins. The material extracted from about $15 \mathrm{mg}$ fixed biopsy tissue was loaded onto 3-4 wells, run and electrotransferred onto Sequi-Blot PVDF membranes. Commercial urinary $\beta_{2} \mathrm{M}$ (Sigma-Aldrich Inc., St Louis, MO, USA) was referred as a normal circulating $\beta_{2} \mathrm{M}^{21}$ It was applied to SDS-PAGE $(2-2.5 \mu \mathrm{g} /$ well) and run together with the extracted sample under the same experimental conditions. The $12 \mathrm{kDa}$ protein bands were excised, pooled and eluted with TFA/acetonitrile/water (3:4:3) as described. ${ }^{22}$ The eluted material was dried in a Speed Vac apparatus.

\section{Isoelectrofocusing}

IEF was performed in a Model 111 Mini IEF Cell (Bio-Rad) on $0.4 \mathrm{~mm}$ thick gels consisting of $5.4 \%$ acrylamide, $0.17 \%$ bis-acrylamide, $2.3 \% \mathrm{pH} 3-10$ ampholyte (Bio-Rad), 6.5\% glycerol, and 6 $\mathrm{M}$ urea. Samples of the purified amyloid $\mathrm{A} \beta_{2} \mathrm{M}$ and the normal $\beta_{2} \mathrm{M}$ were solubilized in an IEF sample buffer consisting of 2\% NP-40 (Sigma Chemical Co., St Louis, MO, USA), 9M urea and $0.002 \% \beta$ mercaptoethanol for $0.5 \mathrm{~h}$ at $37^{\circ} \mathrm{C}$. Samples of the purified $\mathrm{A} \beta_{2} \mathrm{M}$ recovered from about $3 \mathrm{mg}$ starting tissue material and those of the normal $\beta_{2} \mathrm{M}(2 \mu \mathrm{g})$ were loaded per well. Gels were run first for $15 \mathrm{~min}$ at $100 \mathrm{~V}$, then $15 \mathrm{~min}$ at $250 \mathrm{~V}$ and finally for $1 \mathrm{~h}$ at $450 \mathrm{~V}$.

For detection of proteins, gels were stained with Fast Silver stain (Geno Technology, St Louis, MO, USA). For Western blotting, the IEF run samples were transferred onto nitrocellulose membrane and immunostained with polyclonal rabbit antibodies to human $\beta_{2} \mathrm{M}$ (Dako) as described above.

\section{Results}

\section{Pathological Findings}

In case I (Figure 1a), the subtotal colectomy specimen included part of the terminal ileum $(19 \mathrm{~cm}$ length) and right colon up to the sigmoid level (total length $135 \mathrm{~cm}$ ). The main findings were marked dilatation, thinning of the colonic wall and flattening of the mucosal folds. In case II (Figure 1b), the specimen consisted of a colon segment $(29 \mathrm{~cm}$ length) showing a perforation and fibrinopurulent deposition over the serosal surface. The mucosa was flattened, markedly congested and covered with white exudates at the perforation site.
The histological changes were similar in both cases. H\&E-stained sections presented a dense pink amorphous material deposition seen in the submucosal blood vessels wall and in the muscularis propria (Figure 1c). Several giant cells of foreign body-type reaction were seen surrounding these deposits. Additional histological findings in case II were ischemic colitis and acute inflammation. Staining with Crystal Violet showed metachromatic reaction. Tissue sections were Congo-red-positive (Figure 1d) and showed an apple green birefringence under polarized light (Figure 1e), that proved the amyloid nature of the amorphous material seen with H\&E staining. The immunohistochemical analysis (Figure 1f) revealed strong immunoreactivity with anti $\beta_{2} \mathrm{M}$ antibodies.

\section{Biochemical Findings}

The formalin-fixed paraffin-embedded biopsy specimens (cases I and II) were deparaffinized, rehydrated and subjected to the extraction procedure as described above. In both cases, the SDS-PAGE (Figure 2) and Western blot (Figure 3) analyses of the extracted proteins showed the presence of $12 \mathrm{kDa}$ proteins immunoreactive with anti- $\beta_{2} \mathrm{M}$ antibodies. The immunoreactivity of the $24 \mathrm{kDa}$ band was also observed, probably indicating the dimeric form of this protein. The $5 \mathrm{kDa}$ bands present in crude tissue extracts showed no immunoreactivity with anti- $\beta_{2} \mathrm{M}$ antibodies. None of the extracted proteins reacted with either anti- $\kappa$ lightchain or anti- $\lambda$ light-chain antibodies. Amino-terminal amino-acid sequence analysis of the $12 \mathrm{kDa}$ band (case I) revealed a sequence typical of $\beta_{2} \mathrm{M}$ : IQRTPKIQVY (positions 1-10).

The comparative SDS-PAGE and IEF analysis of the tissue $\mathrm{A} \beta_{2} \mathrm{M}$ and normal $\beta_{2} \mathrm{M}$ was carried out according to the Scheme in Figure 4. For the purification of these proteins, the samples run on SDS gels were blotted onto PVDF, and the $12 \mathrm{kDa}$ proteins were eluted from the membrane (Figures 5 and 6). The electrophoretic mobility of the $\mathrm{A} \beta_{2} \mathrm{M}$ was close to that of the normal $\beta_{2} \mathrm{M}$. The purified $\mathrm{A} \beta_{2} \mathrm{M}$ proteins were subjected to IEF, where the closely spaced bands were revealed with Fast Silver stain (Figure 7). These bands were reactive with anti- $\beta_{2} \mathrm{M}$ antibodies (Figure 8). Although the IEF pattern in case I was different from that in case II, in both cases the $\mathrm{A} \beta_{2} \mathrm{M}$ protein bands migrated to a more acidic position as compared to the normal $\beta_{2} \mathrm{M}$.

\section{Discussion}

Systemic amyloid deposition and visceral organ involvement in dialysis-related amyloidosis are now being reported with increasing frequency; ${ }^{23-31}$ however, the data on biochemical features of these amyloid deposits are still lacking. We present 

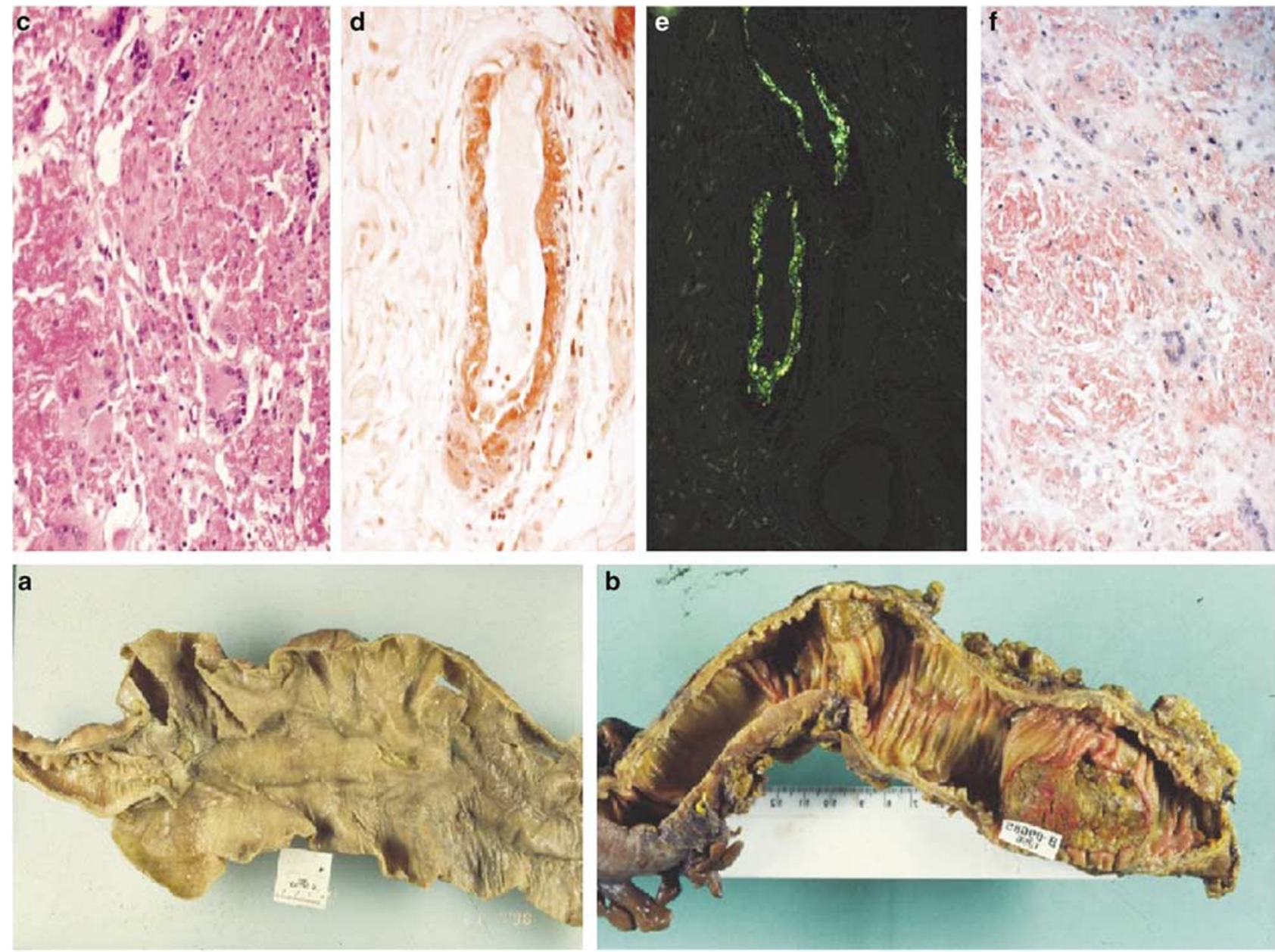

Figure 1 Macroscopic (a and b) and microscopic (c-f) examination of colon tissue specimens in two cases of dialysis-related amyloidosis. (a) Macroscopic examination of case I shows marked dilatation of a large bowel with flattening of the mucosal surface. (b) Mucosal elevation of the perforated area into the gut lumen in case II; (c) H\&E staining (original magnification, $\times 200)$ shows massive deposits of amorphous pink material of amyloid and multinucleated giant cells in the muscularis propria; (d) Congo-red-positive staining of amyloid deposits in the blood vessel walls $(\times 200)$; $(\mathbf{e})$ amyloid deposits in the blood vessel walls exhibit apple green birefringence under polarized light $(\times 100)$; and $(\mathbf{f})$ amyloid deposits demonstrate strongly positive immunostaining for $\beta_{2} \mathrm{M}(\times 100)$.

here a first report on the biochemical analysis of intestinal amyloid deposits found in two cases of hemodialysis-related amyloidosis. The results of our study showed that the extensive amyloid deposition observed in these cases was of $\beta_{2} \mathrm{M}$ origin, whereas the presence of other amyloid types, such as amyloid A (AA) or immunocyte-derived amyloid proteins (AL), was excluded. In both cases, the molecular mass of the deposited protein was very close to that of normal $\beta_{2} \mathrm{M}(12 \mathrm{kDa})$. None of the lower molecular mass $\beta_{2} \mathrm{M}$ degradation products were found, thus supporting the view that $\beta_{2} \mathrm{M}$ proteolysis is not necessary for fibril formation. ${ }^{4,8}$ The extracted amyloid proteins were purified by our recently developed micropreparative SDS-PAGE technique $^{22}$ and afterwards subjected to IEF analysis, which demonstrated a shift to the more acidic pI values as compared to the normal $\beta_{2} \mathrm{M}$. These findings support the hypothesis that amyloid deposits contain the acidic $\beta_{2} \mathrm{M}$ isoforms specific to dialysis-related amyloidosis. Further studies are needed to reveal the precise chemical nature of structural alterations responsible for the appearance of the more acidic $\beta_{2} \mathrm{M}$ isoforms in the gastrointestinal amyloid deposits.

It has been shown that the onset, development and severity of the gastrointestinal amyloidosis in hemodialysis patients correlated with the time of dialysis. ${ }^{27}$ Life-threatening complications such as gastrointestinal hemorrhage and/or intestinal obstruction have been documented in some cases ${ }^{26-30}$ and were also observed in the present study. These findings support the view that gastrointestinal amyloidosis should be considered in any patient maintained on hemodialysis for 10 years or more. $^{26,27}$ As clinical symptoms may be unreliable indicators of gastrointestinal amyloidosis, examination of biopsy specimens with Congo-red and immunostains becomes critical. ${ }^{27}$ It should also be noted that besides $\beta_{2} \mathrm{M}$ amyloidosis, deposition of 

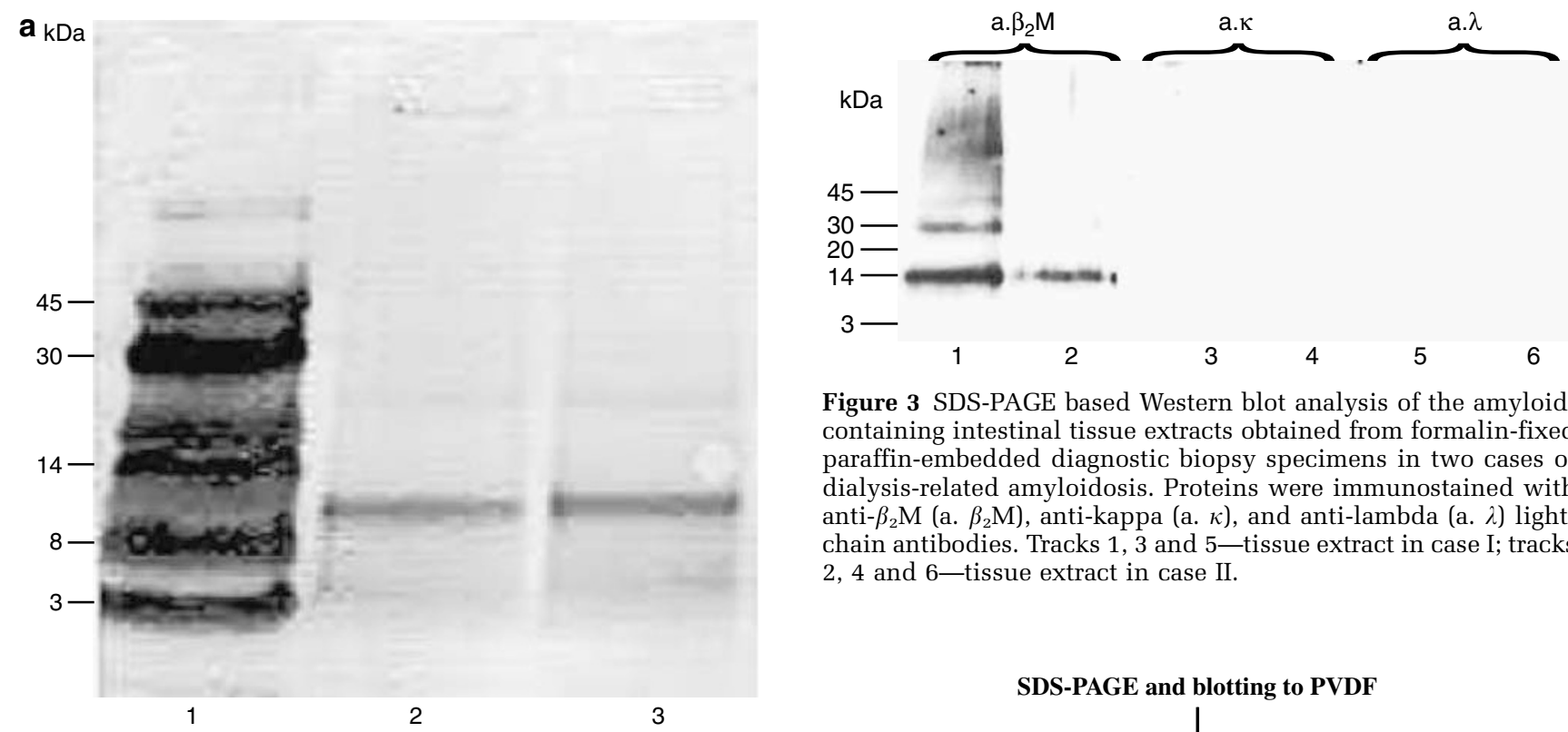

Figure 3 SDS-PAGE based Western blot analysis of the amyloidcontaining intestinal tissue extracts obtained from formalin-fixed paraffin-embedded diagnostic biopsy specimens in two cases of dialysis-related amyloidosis. Proteins were immunostained with anti- $\beta_{2} \mathrm{M}$ (a. $\beta_{2} \mathrm{M}$ ), anti-kappa (a. $\kappa$ ), and anti-lambda (a. $\lambda$ ) lightchain antibodies. Tracks 1, 3 and 5-tissue extract in case I; tracks 2, 4 and 6-tissue extract in case II.

b kDa

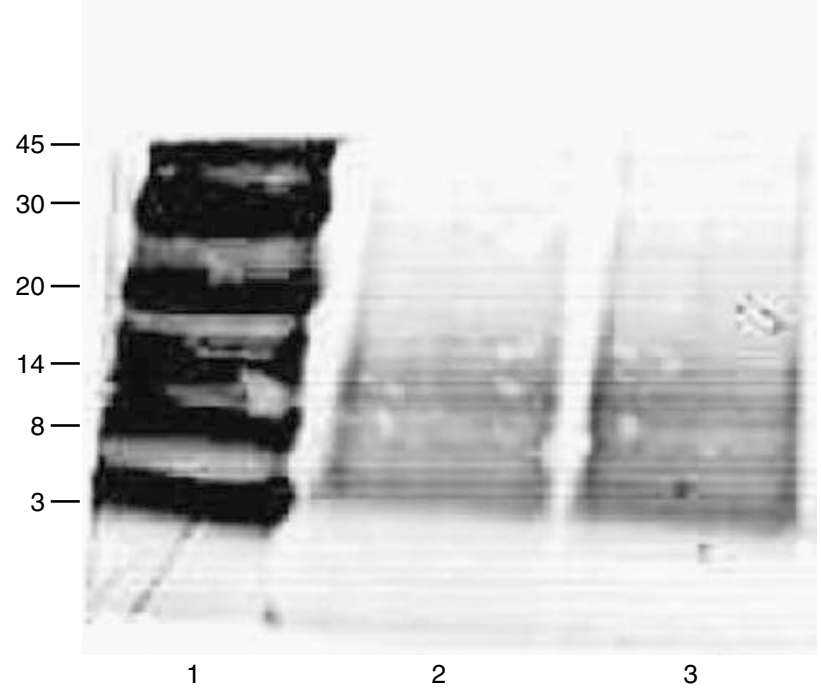

Figure 2 SDS-PAGE analysis of the amyloid-containing intestinal tissue extracts obtained from formalin-fixed paraffin-embedded diagnostic biopsy specimens in two cases of dialysis-related amyloidosis. Proteins were visualized by Commassie blue staining. (a) Track 1-molecular weight markers, tracks 2 and 3-tissue extract in case I; (b) track 1-molecular weight markers, tracks 2 and 3-tissue extract in case II.

other amyloid types, such as AA and AL, has been documented in several cases of dialysis-related amyloidosis. ${ }^{31-34}$ Since the treatment of amyloidosis depends on the chemical type of this disease, the reliable confirmation of the $\beta_{2} \mathrm{M}$ amyloid origin excluding the presence of other amyloid types is imperative in dialysis-related amyloidosis..33 The immunohistochemical amyloid typing methods are used routinely to provide this information, but in some instances, the obtained results can be incon-
SDS-PAGE and blotting to PVDF

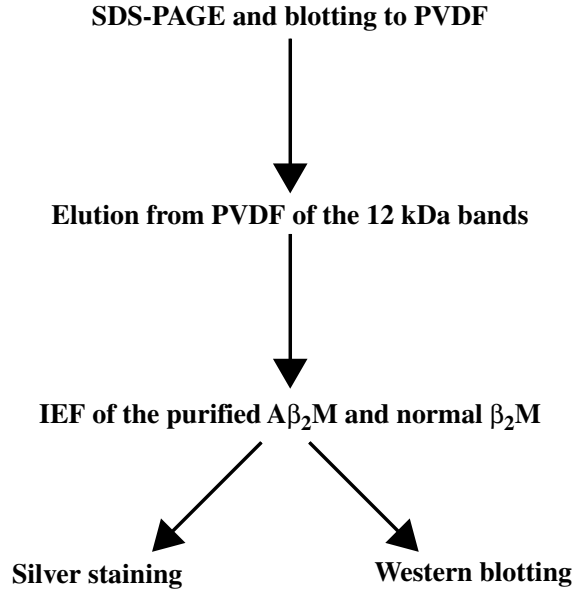

Figure 4 Flowchart of a comparative analysis of the amyloidcontaining tissue $\mathrm{A} \beta_{2} \mathrm{M}$ and normal $\beta_{2} \mathrm{M}$ proteins.

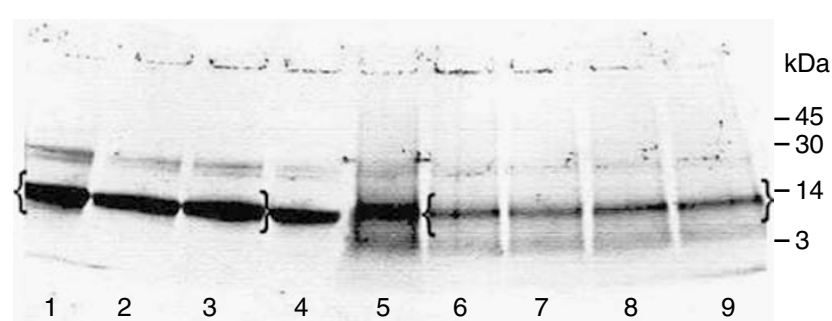

Figure 5 SDS-PAGE of the normal $\beta_{2} \mathrm{M}$ (tracks 1-4) and $\mathrm{A} \beta_{2} \mathrm{M}$ containing tissue extract (tracks $5-9$ ). The electrophoretically run proteins were blotted to PVDF membranes, and the $12 \mathrm{kDa}$ protein bands (in brackets) were excised, pooled and eluted. The purified normal $\beta_{2} \mathrm{M}$ and the tissue $\mathrm{A} \beta_{2} \mathrm{M}$ were further examined by IEF (Figures 7 and 8).

clusive, especially in relation to AL proteins. ${ }^{35} \mathrm{In}$ this respect, our biochemical micromethods ${ }^{15,16}$ applied in this study were helpful in identifying unequivocally the chemical nature of the deposited amyloid. 


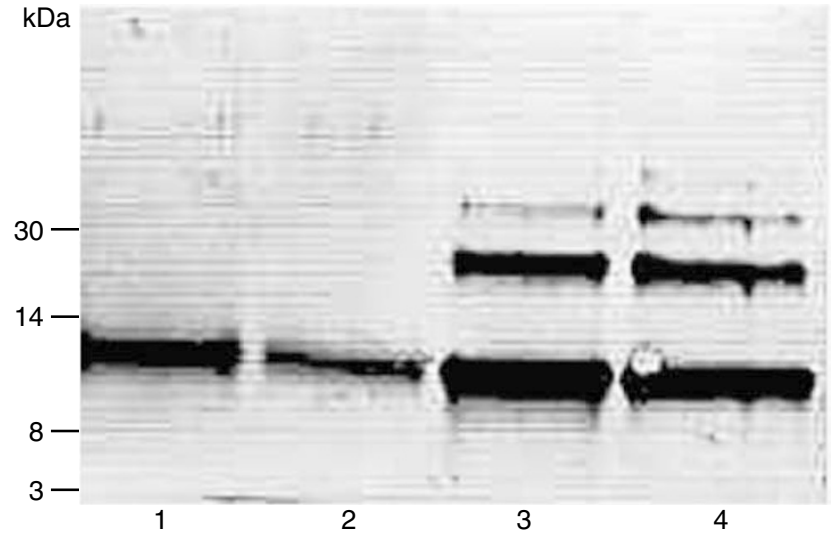

Figure 6 SDS-PAGE of the tissue $\mathrm{A} \beta_{2} \mathrm{M}$ purified following SDS electrophoresis, blotting to and elution from PVDF membranes. Tracks 1 and 2 -purified $\mathrm{A} \beta_{2} \mathrm{M}$; tracks 3 and 4 -normal $\beta_{2} \mathrm{M}$.

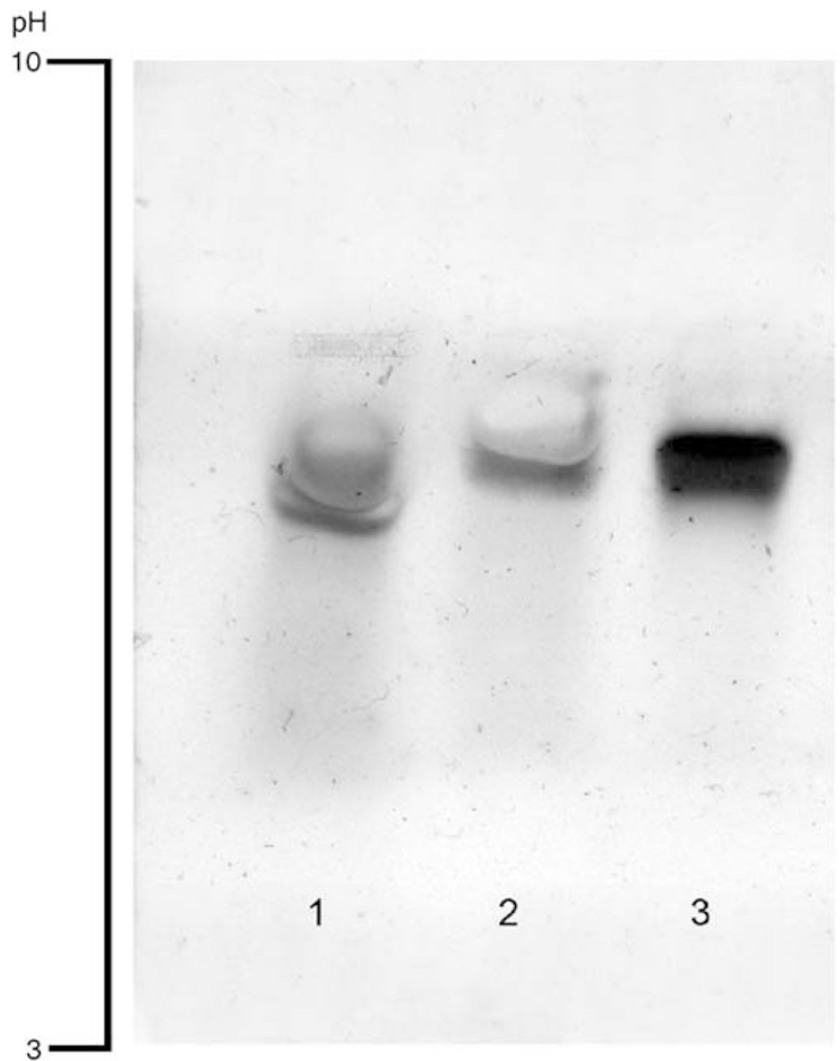

Figure 7 IEF of the tissue $\mathrm{A} \beta_{2} \mathrm{M}$ (track 1 -case II, track 2-case I) and normal $\beta_{2} \mathrm{M}$ (track 3 ). Proteins were detected with Fast Silver stain.

It should be emphasized, however, that biochemical examination of amyloid proteins in the diagnostic biopsy specimens faces two major difficulties: small quantities of the available tissue material and decreased solubility of proteins due to tissue fixation with formalin. ${ }^{36,37}$ In fact, previous biochemical studies on $\mathrm{A} \beta_{2} \mathrm{M}$ proteins were performed using larger amounts of fresh (unfixed) tissues obtained at autopsy $y^{5,8,12}$ or at carpal tunnel
$\mathrm{pH}$

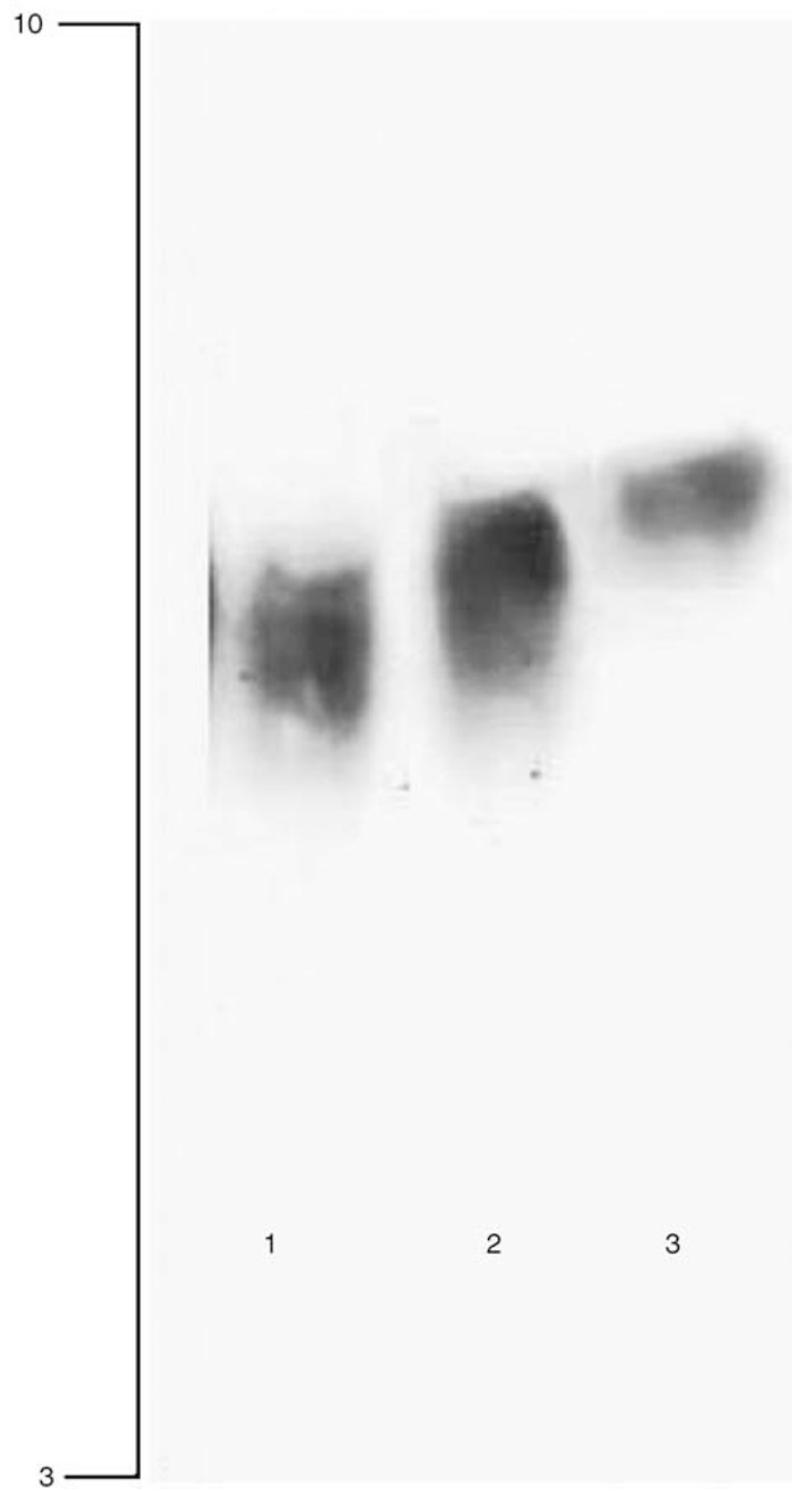

Figure 8 IEF based western blot analysis of tissue $\mathrm{A} \beta_{2} \mathrm{M}$ (track 1 case II, track 2 - case I) and the normal $\beta_{2} \mathrm{M}$ (track 3 ). Proteins were immunostained using anti- $\beta_{2} \mathrm{M}$ antibodies.

release operations. ${ }^{4,10}$ In these studies, the classical amyloid isolation methods, which include the water extraction method of Pras ${ }^{10,12,38}$ and the guanidine hydrochloride solubilization technique ${ }^{4,5,8}$ were successfully used, but these methods were found unsuitable for biochemical examination of small fixed biopsy specimens. Recently, we reported a new simple formic acid microextraction technique allowing the recovery and chemical typing of amyloid in small formalin-fixed biopsy specimens. ${ }^{15,16}$ Application of this microtechnique in the present study, together with our small-scale amyloid purification method, ${ }^{22}$ made possible the first biochemical characterization of the intestinal amyloid deposits in dialysis-related amyloidosis. Our study was based on previous findings ${ }^{39,40}$ 
showing that amyloid, in contrast to many other proteins, is not affected by formalin fixation, probably because beta-pleated sheet conformation of amyloid prevents formalin infiltration. In fact, formalin fixation is even thought to be advantageous for the purification of amyloid proteins. ${ }^{40}$ Thus, it is most likely that the observed shift of $\mathrm{A} \beta_{2} \mathrm{M}$ proteins to more acidic pI values represents a disease-related condition rather than an artifact caused by tissue fixation with formalin.

Finally, application of our microtechniques was useful in obtaining precise diagnosis of amyloidosis, which is necessary for effective therapy. Usage of these techniques in the analysis of different visceral tissues affected by dialysis-related amyloidosis could provide new important information on the chemical structure of amyloid proteins and contribute to our understanding of the pathogenesis of this devastating disease.

\section{Acknowledgements}

We thank Mrs Janna Livshits (Department of Pathology, Western Galilee Hospital, Nahariya Medical Center, Israel) for her technical assistance in the immunohistochemical studies; Mr Yotam Hadass and Mrs Linda Gans (Heller Institute of Medical Research, Sheba Medical Center, Tel-Hashomer, Israel) for their help in the preparation of this manuscript.

\section{References}

1 Akash N. Dialysis-related amyloidosis: pathogenesis and promoting factors (a review). Dial Transplant 2000;29:325-329.

2 Zingraff J, Drueke T. $\beta_{2}$ Microglobulin amyloidosis: past and future. Artif Organs 1998;22:581-584.

3 Drueke TB. $\beta_{2}$ Microglobulin and amyloidosis. Nephrol Dial Transplant 2000;15(Suppl 1):17-24.

4 Gejyo F, Yamada T, Odani Y, et al. A new form of amyloid protein associated with chronic hemodialysis was identified as beta 2-microglobulin. Biochem Biophys Res Commun 1985;129:701-706.

5 Gorevic PD, Casey TT, Stone WJ, et al. Beta-2 microglobulin is an amyloidogenic protein in man. J Clin Invest 1985;76:2425-2429.

6 Shirama T, Skinner M, Cohen AS, et al. Histochemical and immunohistochemical characterization of amyloid associated with chronic hemodialysis as $\beta_{2}$-microglobulin. Lab Invest 1985;53:705-709.

7 Casey TT, Stone WS, DiRaimondo CR, et al. Tumoral amyloidosis of bone of beta 2-microglobulin origin in association with long-term hemodialysis; a new type of amyloid disease. Hum Pathol 1986;17:731-738.

8 Gorevic PD, Munoz PC, Casey TT, et al. Polymerization of intact $\beta_{2}$-microglobulin in tissue causes amyloidosis in patients with chronic hemodialysis. Proc Natl Acad Sci USA 1986;83:7908-7912.

9 Linke RP, Hampel H, Lobeck H, et al. Lysine-specific cleavage of $\beta_{2}$-microglobulin in amyloid deposits associated with hemodialysis. Kidney Int 1989;36: 675-681.

10 Miyata $\mathrm{T}$, Oda $\mathrm{O}$, Inagi $\mathrm{R}$, et al. $\beta_{2}$-Microglobulin modified with advanced glycation end products is a major component of hemodialysis-associated amyloidosis. J Clin Invest 1993;92:1243-1252.

11 Miyata T, Inagi R, Wada T, et al. Glycation of human $\beta_{2}$-microglobulin in patients with hemodialysis-associated amyloidosis: identification of the glycation sites. Biochemistry 1994;33:12215-12221.

12 Miyata T, Taneda S, Kawai R, et al. Identification of pentosidine as a native structure for advanced glycation end products in $\beta_{2}$-microglobulin-containing amyloid fibrils in patients with dialysis-related amyloidosis. Proc Natl Acad Sci USA 1996;93: 2353-2358.

13 Odani H, Oyama R, Titani K, et al. Purification and complete amino acid sequence of novel $\beta_{2}$-microglobulin. Biochem Biophys Res Commun 1990;168: 1223-1229.

14 Ogawa H, Saito A, Nakajima M, et al. Detection of a novel $\beta_{2}$-microglobulin in the serum of hemodialysis patients and its amyloidogenic predisposition. Clin Nephrol 1998;30:158-163.

15 Argiles A, Garcia-Garcia M, Derancourt J, et al. Beta 2 microglobulin isoforms in healthy individuals and in amyloid deposits. Kidney Int 1995;48:1397-1405.

16 Argiles A, Mourad G, Gouin-Charnet A, et al. Antiproteases and cells in the pathogenesis of $\beta_{2}$-microglobulin amyloidosis: role of $\alpha_{2}$-macroglobulin and macrophages. Nephron 2000;86:1-11.

17 Argiles A, Charnet A, Schmitt-Bernard CF, et al. $\beta_{2}$-microglobulin amyloidosis. In: Grateau G, Kyle RA, Skinner M (eds). Amyloid and Amyloidosis. CRC Press, Boca Raton: London, New York, Washington, DC, 2005, pp 415-417.

18 Kaplan B, Martin BM, Livneh A, et al. Biochemical subtyping of amyloid formalin-fixed tissues samples confirms and supplements immunohistological data. Am J Clin Pathol 2004;121:794-800.

19 Kaplan B, Martin BM, Cohen HI, et al. Primary local orbital amyloidosis: biochemical identification of the immunoglobulin light chain $\kappa$ III subtype in an small formalin fixed, paraffin wax embedded tissue sample. J Clin Pathol 2005;58:539-542.

20 Kaplan B, Yakar S, Kumar A, et al. Immunochemical characterization of amyloid in diagnostic biopsy tissue. Amyloid: Int J Exp Clin Med 1997;4:80-86.

21 Berggard I, Bearn AG. Isolation and properties of a low molecular weight $\beta_{2}$ globulin occurring in human biological fluids. J Biol Chem 1968;243:4095-4103.

22 Kaplan B, Murphy CL, Ratner V, et al. Micro-method to isolate and purify amyloid proteins for chemical characterization. Amyloid: J Protein Folding Disord 2001;8:22-29.

23 Campistol JM, Cases A, Torras A, et al. Visceral involvement of dialysis amyloidosis. Am J Nephrol 1987;7:390-393.

24 Noel LH, Zingraff J, Bardin T, et al. Tissue distribution of dialysis amyloidosis. Clin Nephrol 1987;27: 175-178.

25 Choi HS, Heller D, Picken MM, et al. Infarction of intestine with massive amyloid deposition in two patients on long-term hemodialysis. Gastroenterology 1989;96:230-234.

26 Araki H, Muramoto H, Oda K, et al. Severe gastrointestinal complications of dialysis-related amyloido- 
sis in two patients on long-term hemodialysis. Am J Nephrol 1996;16:149-153.

27 Jimenez RE, Price DA, Pinkus GS, et al. Development of gastrointestinal beta 2-microglobulin amyloidosis correlates with time on dialysis. Am J Surg Pathol 1998;22:729-735.

28 Shimizu M, Manabe T, Matsumoto T, et al. Beta 2-microglobulin haemodialysis related amyloidosis: distinctive gross features of gastrointestinal involvement. J Clin Pathol 1997;50:873-875.

29 Kanai H, Kachiwagi M, Hirakata H, et al. Chronic intestinal pseudo-obstruction due to dialysis-related amyloid deposition in the propria muscularis in a hemodialysis patient. Clin Nephrol 2000;53:294-399.

30 Van Audenhove A, Vandermarliere A, Lerut E, et al. beta $2 \mathrm{M}$-amylodosis and gastrointestinal bleeding after renal transplantation. Acta Clin Belg 2003;58:248-250.

31 Zingraff J, Droz D, Youam M, et al. Chronic arthropathy and rectal bleeding in a long-term hemodialysis patient. Nephrol Dial Transplant 1994;10:2153-2155.

32 Fernandez-Alonso J, Rios-Camacho C, ValenzuelaCastano A, et al. Mixed systemic amyloidosis in a patient receiving long-term haemodialysis. J Clin Pathol 1994;47:560-561.

33 Fenves AZ, Stone MJ, Johnson KB. Systemic primary amyloidosis in chronic hemodialysis. BUMC Proc 1999;12:61-64.
34 Bely M, Lakatos T, Apathy A. Systemic B2-microglobulin-related amyloidosis in a patient with chronic renal failure, receiving long term hemodialysis for 3 years-a light and electron microscopic study. In: Grateau G, Kyle RA, Skinner M, (eds). Amyloid and Amyloidosis. CRC Press, Boca Raton: London, New York, Washington, DC, 2005, pp 429-431.

35 Gallo GR, Feiner HD, Chuba JV, et al. Characterization of amyloid by immunofluorescence microscopy. Clin Immunol Immunopathol 1986;39:479-490.

36 Kaplan B, Hrncic R, Murphy CL, et al. Microextraction and purification techniques applicable to chemical characterization of amyloid proteins in minute amounts of tissue. Methods Enzymol 1999;309:67-81.

37 Kaplan B, Shtrasburg S, Pras M. Micropurification techniques in the analysis of amyloid proteins. J Clin Pathol 2003;56:86-90.

38 Pras M, Schubert M, Zucker-Franklin D, et al. The characterization of soluble amyloid prepared in waster. J Clin Invest 1968;47:924-933.

39 Layfield R, Baily K, Lowe J, et al. Extraction and protein sequencing of immunoglobulin light chain from formalin-fixed cerebrovascular amyloid deposits. J Pathol 1996;180:455-459.

40 Layfield R, Bailey K, Dineen R, et al. Application of formalin fixation to the purification of amyloid proteins. Anal Biochem 1997;253:142-144. 